\title{
PEMANFAATAN ALAM TERBUKA SEBAGAI SUMBER BELAJAR BIOLOGI
}

\author{
Sulis Anjarwati \\ Universitas Nahdlatul Ulama Lampung \\ Email: sulis.anjarwati.sa@gmail.com
}

\begin{abstract}
Learning activities are an effort to improve the quality of education. The learning process is carried out in order to achieve competent human resources. Various ways are done to achieve the results as expected, one of which presents various forms of learning resources so that students gain experience that can improve their own quality. Learn one source of learning for students who study science/biology, namely the environment / open environment. One of the outdoors that can be used as a learning resource is the river. This study aims to describe the use of nature as a source of leaming. The object of this research is the $38 B$ Banjarrejo river, the study was conducted by observing the state of the river. The research results are in the form of descriptions. It is known that the 38B Banjarrejo river has potential usefulness to be used as one of the learning resources for junior high school/MTs students in Metro City. The use of the river as a learning resource can be used as a process of training problem-solving skills and can improve the character abilities of students by looking at the state of the surrounding environment that requires handling problems.
\end{abstract}

Kata Kunci: Su mber Belajar, Alam terbuka

\section{PENDAHULUAN}

Kegiatan pembelajaran merupakan salah satu upaya atau suatu bentuk usaha yang dilakukan untuk memperoleh perubahan kearah yang lebih baik terutama tingkah laku ataupun pengetahuan melalui pengalaman yang diterima oleh setiap individu dalam bentuk interaksi dengan lingkungannya (Slameto, 2003). Adanya perubahan tingkah laku merupakan hasil pembelajaran meliputi aspek sikap, pengetahuan, dan keterampilan.

Proses belajar yang dilakukan bertujuan untuk meningkatkan kualitas pendidikan yang diterima oleh setiap individu. Kualitas pendidikan perlu ditingkatkan agar diperoleh sumber daya manusia yang kompeten. Upaya peningkatan kualitas pendidikan dilakukan dengan melibatkan peserta didik secara aktif dalam proses pembelajaran. Salah satu upaya yang dapat dilakukan yaitu dengan mengahadirkan sumber belajar yang dapat membuat peserta didik terlibat langsung didalamnya. Sumber belajar yang dapat digunakan dalam proses pembelajaran salah satunya yaitu alam terbuka. Berdasarkan hasil analisis kebutuhan sumber belajar yang telah dilakukan di SMP/MTs Kota Metro, Lampung diketahui bahwa untuk meningkatkan keterampilan peserta didik perlu adanya penyediaan sumber belajar bagi peserta didik salah satunya 
sumber belajar berbasis keterampilan proses sains (Anjarwati, 2016).

Keterampilan proses sains (KPS) merupakan keterampilan dasar dalam bereksperimen, metode ilmiah, dan bersikap inkuiri yang dilakukan dalam proses pembelajaran (Prasetyo, 2011; Raj \& Devi, 2014). Sumber belajar yang dapat digunakan untuk meningkatkan kemampuan tersebut salah satunya dengan menghadirkan pembelajaran dengan memanfaatkan pembelajaran menggunakan alam /lingkungan terbuka.

Alam terbuka merupakan tempat belajar yang memiliki banyak ilmu, baik dalam meningkatkan pengetahuan peserta didik juga dalam mengembangkan karakter peserta didik. Proses pembelajaran di alam terbuka akan memberikan pengalaman langsung dan menumbuhkan rasa "Willing to learn and change" yang dapat dijadikan dasar dalam meningkatkan kualitas diri (Siahaan \& Prastowo, 2014).

Alam terbuka yang dapat dijadikan sebagai sumber belajar biologi salah satunya yaitu ekosistem di air sungai. Sungai merupakan salah satu sumber belaar yang dapat dijadikan rujukan bagi peserta didik dalam mempelajari materi ekosistem. Ekosistem merupakan suatu bentuk hubungan saling ketergantungan antara makhluk hidup dan lingkungannya yang membentuk suatu kesatuan fungsional (Kadaryanto, 2006).
Laporan berikut merupakan salah satu bentuk hasil kajian yang bertujuan untuk menganalisis kebermanfaatan alam terbuka sebagai sumber belajar biologi bagi peserta didik SMP/MTs pada materi eksositem dengan objek yang digunakan yaitu sungai.

\section{METODE}

Penelitian ini merupakan penelitian deskriptif. Penelitian ini melaporkan tentang deskripsi pemanfaatan alam terbuka dalam hal ini adalah sungai sebagai salah satu sumber belajar biologi pada materi Ekosistem bagi peserta didik tingkat SMP/MTs di Kota Metro, Lampung. Subjek penelitian ini yaitu kondisi fisik perairan sungai 38B Banjarrejo Kabupaten Lampung Timur yang akan dimanfaatkan sebagai sumber belajar biologi SMP/MTs pada materi Ekosistem. Proses pengumpulan data melalui pengamatan menggunakan beberapa alat yaitu kamera, alat tulis, dan kantong plastik. Identifikasi yang dilakukan yaitu berkaitan dengan keadaan sungai 38B Banjarrejo yang dibatasi pada keadaan fisik sungai.

\section{HASIL DAN PEMBAHASAN}

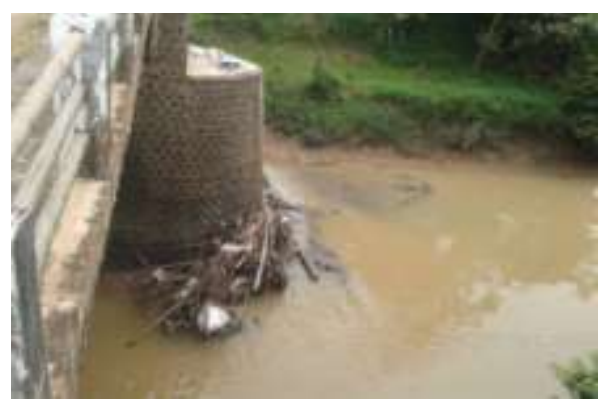

Gambar 1. Berbagai Macam Sampah Plastik disekitar tepi Sungai 


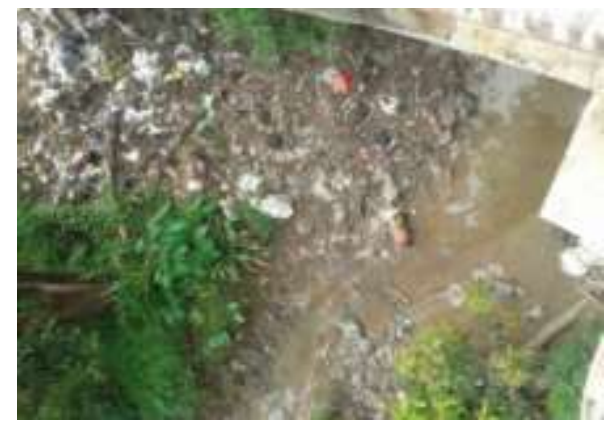

Gambar 2. Berbagai Macam Sampah yang Tersangkut di bagian Tengah

Sungai

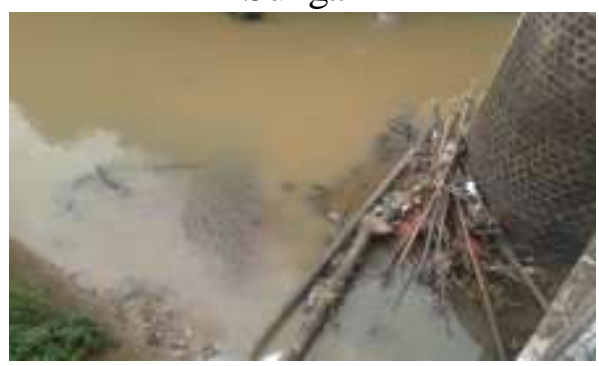

Gambar 3. Air yang Terlihat Jelas

Berwarna Keruh

Ekosistem merupakan salah satu materi dalam pembelajaran IPA/Biologi yang lebih mudah dipelajari dengan cara langsung mengamati objek sekitar lingkungan, salah satunya di sekitar lingkungan sekolah. Materi Ekosistem dapat disampaikan langsung menggunakan objek lingkungan karena materi ini berhubungan langsung dengan alam (Mustaqim, 2012).

Pemanfaatan lingkungan sekitar sekolah dalam proses pembelajaran diharapkan dapat membangkitkan motivasi dan membantu keefektifan kegiatan pembelajaran. Selain itu, pemanfaatan lingkungan atau alam terbuka sebagai sumber belajar juga dapat meningkatkan konsentrasi peserta didik, menjadikan pembelajaran lebih bervariasi sehingga peserta didik tidak bosan, tidak menjadikan peserta didik pasif. Menurut Sudjana \& Rivai
(2001) terdapat tiga macam lingkungan yang dapat digunakan dalam proses pendidikan dan pengajaran yaitu lingkungan sosial, lingkungan alam, dan lingkungan buatan. Lingkungan alam merupakan segala sesuatu yang sifatnya ilmiah seperti keadaan geografis, iklim maupun sumber daya alam. Pemanfaatan alam sebagai sumber belajar dapat dilakukan dengan dua cara yaitu dengan menghadirkan sumber belajar (lingkungan) ke dalam kelas dan dengan cara membawa peserta didik ke lingkungan.

Salah satu lingkungan/alam terbuka yang dapat digunakan sebagai sumber belajar yaitu Sungai. Sungai sebagai salah satu objek pembelajarn IPA/Biologi bagi peserta didik tingkat SMP/MTs dapat memberikan pengalaman yang bermakna bagi mereka. Peserta didik SMP/MTs di Kota Metro dapat memanfaatkan ekosistem sungai yang terdapat di perbatasan Kota Metro dan Desa Banjarrejo 38B, Kabupaten Lampung Timur.

Sungai tersebut terdapat di lokasi yang mudah dijangkau, karena letaknya tepat dipinggir jalan raya. Berdasarkan hasil identifikasi diketahui bahwa aktifitas masyarakat disekitar sungai tersebut paling banyak adalah tempat pemukiman penduduk yang digunakan sebagai penyewaan tempat tinggal mahasiswa (Tempat Kos). 
Berdasarkan hasil pengamatan diketahui bahwa sungai tersebut diketahui telah mengalami pencemaran air secara fisik, berikut gambar sungai 38B Banjarrejo, Lampung Timur.

Berdasarkan hasil identifikasi terlihat berbagai macam sampah, dan kayu berserakan di sekitar sungai. Pemandangan ini menjadi salah satu hal yang sangat buruk dan jelas memberikan sumbangan yang sangat besar dalam pencemaran air di sungai 38B Banjarrejo Lampung Timur. Limbah hasil aktivitas masyarakat menjadi salah satu penyumbang terbesar terhadap kualitas sungai yang buruk karena kurangnya kesadaran untuk tidak membuang sampah di sekitar sungai.

Pembuangan sampah di sekitar tempat tinggal warga yang kurang baik juga menjadi sumber berkumpulnya sampah di sekitar sungai. Hal tersebut karena aliran atau arus membawa sampah-sampah tersebut berkumpul di sekitar sungai.

Kekeruhan adalah gambaran sifat optik air suatu perairan yang ditentukan berdasarkan banyaknya sinar (cahaya) yang dipancarkan dan diserap oleh partikel-partikel yang ada dalam air (Sasongko, 2006: Fadly, 2008). Kekeruhan air sungai sangat terlihat dengan warna air sungai yang coklat hampir pekat. Tingkat kekeruhan yang tinggi berpengaruh akan terganggunya berbagai organisme akuatik seperti sistem pernapasan dan daya lihatnya, serta dapat menghambat penetrasi cahaya ke dalam air. Tingkat

kekeruhan yang tinggi dapat menyulitkan usaha penyaringan dan mengurangi efektivitas desinfektan pada proses penjernihan air (Dini, 2011). Menurut Sutamihardja \& Husin, 1983 kekeruhan yang tinggi akan mengurangi fotosintesis tumbuhan yang hidup di dalam air, perakaran vegetasi perairan dan ganggang, sehingga berefek menekan produktivitas ikan. Tingkat kekeruhan dan kecerahan menjadi parameter dalam menentukan produktivitas suatu perairan. Meningkatnya kekeruhan akan menurunkan kecerahan perairan.

Kekeruhan air di sungai 38B Banjarrejo akibat banyaknya sumber limbah yang tidak dikelola dengan baik. Salah satunya yaitu limbah padat domestik. Sampah yang tidak ditangai akan dibuang ke badan air dan menjadi pencemar tambahan (Sasongko, 2006, Fadly, 2008).

Akibat dari pencemaran
perairan di sungai berpengaruh
dengan
keanekaragaman atau punahnya
populasi organik meliputi perifiton,
bentos, dan plankton. Berkurangnya
organisme-organime perairan akan
berpengaruh terhadap sistem ekologi
perairan tersebut. Ekosistem
mempunyai peran penting dalam
mengembalikan lingkungan yang
telah tercemar kearah pemurnian
selama batas daya dukung
lingkungan yang bersangkutan. Jika
beban pencemaran melebihi daya
dukung lingkungannya maka
kemampuan itu tidak dapat
digunakan lagi. Pencemaran air


berdampak buruk bagi kesehatan makhluk hidup, karena di dalam air yang tercemar mengandung mikroorganisme yang patogen, serta berbagai komponen yang beracun.

Berdasarkan hasil identifikasi yang dilakukan berkaitan dengan eksosistem sungai 38B Banjarrejo Lampung Timur tersebut diketahui bahwa sungai tersebut telah mengalami pencemaran secara fisik yang diketahui dari adanya warna air sugai yang tidak jernih, bau air sungai, dan tingkat kekeruhan.

Informasi tersebut dapat dijadikan sebagai salah satu sumber belajar biologi/IPA bagi peserta didik tingkat SMP/MTs. Lingkungan alam terbuka tersebut menjadi objek pengamatan peserta didik untuk melakukan identifikasi berkaitan dengan faktor pencemaran air sungai, cara melakukan pengendalian agar terhindarnya pencemaran air sungai, dan lain sebagainya. Oleh karena itu, baik untuk dilakukan pengamatan langsung oleh peserta didik tingkat SMP/MTs yang ada di Kota Metro sehingga dapat meningkatkan kemampuan Problem Solving dari diri peserta didik setelah melihat langsung keadaan lingkungan sekitar tempat tinggal mereka.

\section{KESIMPULAN}

Berdasarkan hasil pemaparan di atas dapat disimpulkan bahwa lingkungan/alam terbuka salah satunya sungai, dapat dijadikan sebagai sumber belajar biologi/IPA bagi peserta didik tingkat SMP/MTs untuk melatih kemampuan problem solving dan dapat meningkatkan kemampuan karakter peserta didik dengan melihat keadaan lingkungan sekitar yang membutuhkan penanganan masalah.

\section{SARAN}

Pendidik dapat langsung mengajak peserta didik mengamati objek sungai yang ada di daerah 38B Banjarrejo dengan mengajak rekan guru untuk mendampingi peserta didik. Pendidik dapat menyiapkan alat yang diberikan kepada peserta didik dalam melakukan pengamatan sehingga peserta didik mendapatkan informasi sesuai dengan yang diharapkan, sehingga mereka dapat secara langsung mencari solusi dari permasalahan yang mereka temukan.

\section{DAFTAR RUJUKAN}

Anjarwati, S. 2017. Analysis of Material Teaching Biological Needs Based Science Process Skill Student. RETEL Journal: Research on Teaching and Language Journal. Vol. 3 No. 2. Hal. 39-43.

Dini, S. 2011. Evaluasi Kualitas Air Sungai Ciliwung di Provinsi Daerah Khusus Ibu Kota Jakarta Tahun 2000-2010. Skripsi. Jakarta. Universitas Indonesia.

Fadly, N. A. 2008. Daya Tampung dan Daya Dukung Sungai Ciliwung serta Strategi Pengelolaannya. Tesis. Program Studi Teknik Sipil, Program Pascasarjana Bidang 
Ilmu Teknik, Universitas Indonesia.

Kadaryanto. 2006. Biologi. Jakarta.

Yudistira, Hal: 179.

Mustaqim, M. 2012. Meningkatkan

Hasil Belajar melalui

Pemanfaatan Lingkungan

Sekitar Sekolah sebagai

Sumber Belajar pada Kelas

VII F SMP Muhammadiyah 1

Surakarta Tahun Ajaran

2011-2012. Universitas

Muhammadiyah Surakarta.

Prasetyo, Z. K. 2011.

Pengembangan Perangkat

Pembelajaran Sains Terpadu

Untuk Meningkatkan

Kognitif, Keterampilan

Proses, Kreativitas Serta

Menerapkan Konsep Ilmiah

Peserta Didik SMP. Laporan

Penelitian DIPA BLU UNY

Tahun Anggaran 2010.

Yogyakarta. Universitas

Negeri Yogyakarta.

Raj, R. G. \& Devi, S. N. 2014.

Science Process Skills And

Achievement In Science

Among High School

Students. Scholarly Research

Journal for Interdisciplinary

Studies, 2 (15): 2435-2443.

Siahaan, W. \& Prastowo, P. 2014.

Pengaruh Pemanfaatan

Lingkungan Sekitar Sekolah

Terhadap Hasil Belajar Siswa

pada Materi Pokok

Ekosistem. Prosiding

Seminar Nasional Biologi

dan Pembeajarannya.

Medan. 25 Agustus 2014.
Sasongko, L.A. 2006. Kontribusi Air Limbah Domestik Penduduk Sekitar Sungai Tuk terhadap Kualitas Air Sungai Kaligarang serta Upaya Penanganannya. Tesis Program Studi Magister Ilmu Lingkungan. Universitas Diponegoro. Semarang.

Slameto. 2003. Belajar dan Faktorfaktor yang Mempengaruhinya. Jakarta. PT Rineka Karya, Hal: 2, 5-8. Sudjana, N. \& Rivai, A. 2001. Media Pengajaran (Penggunaan dan Pembuatannya). Bandung. Sinar Baru Bandung. 